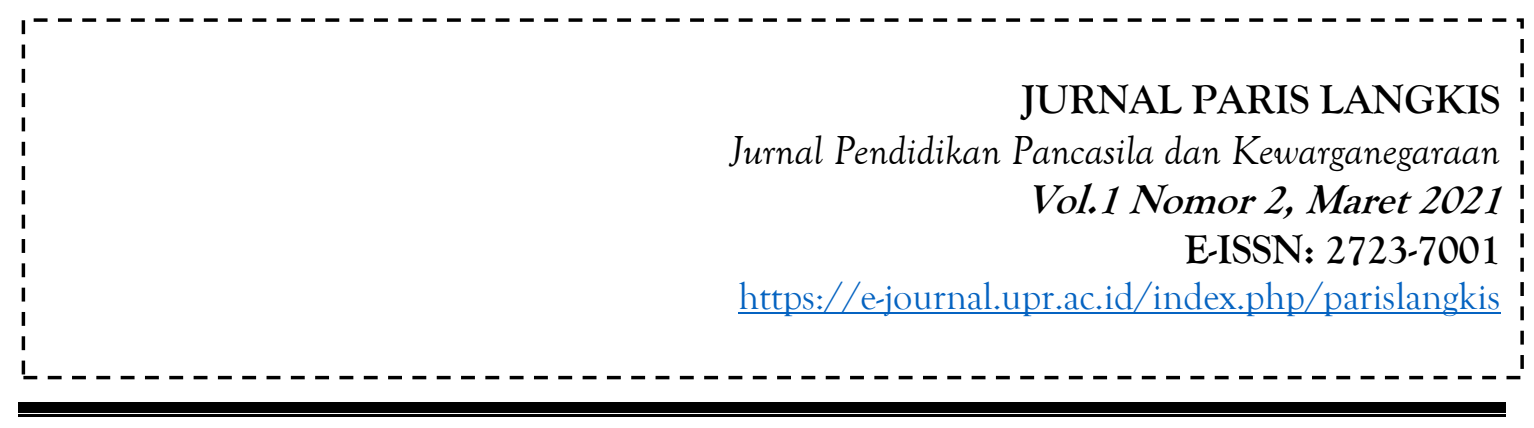

\title{
PEMANFAATAN SERTA OPTIMALISASI PENGGUNAAN HUKUM PIDANA SECARA ADAT DALAM MENCIPTAKAN KEADILAN BAGI KORBAN DAN PELAKU
}

\author{
Neo Adhi Kurniawan
}

Jurusan Hukum dan Kewarganegaraan, Prodi Pendidikan Pancasila dan Kewarganegaraan, Fakultas Ilmu Sosial, Universitas Negeri Malang

e-mail:neo.adhi.fis@um.ac.id

\begin{abstract}
Abstrak:
Keberadaan Hukum Adat masih dirasakan sangat perlu untuk dipelihara dan dipertahankan ditengah-tengah adanya hukum Pidana, Perdata, adminstrasi Negara serta hukum-hukum Negara yang lainnya. Menurut pendapat dari Soepomo, ada sekurang-kurangnya 4 (empat) alasan untuk mempertahankan eksistensi atau keberadaan hukum adat diantaranya yakni karena hukum adat (a) mempunyai sifat kebersamaan atau komunal yang kuat; (b) mempunyai corak religio-magis dalam pandangan hidup; (c) diliputi oleh pikiran penataan serba konkrit, yang artinya sangat memperhatikan banyaknya dan berulang-ulangnya perhubungan hidup yang konkrit; dan (d) mempunyai sifat yang visual, yang dalam perhubungan hukum dianggap hanya terjadi oleh karena ditetapkan dengan suatu ikatan tanda yang dapat dilihat. Penulisan aetikel ini mengunakan metode analisis yuridis normative, yaitu pedekatan yang menggunakan bahan hukum utama berupa peraturan perundang-ndangan yang berhubungan dengan judul serta menggunakan penelaan teoriteori, konsep-konsep serta asas-ass hukum yang berlaku tentang sejauh mana optimalisasi penerapan hukum pidana secara adat dalam menyelesaikan permasalahan serta memberikan keadilan baik bagi korban dan pelaku. Apabila jerjadi sebuah perbuatan atau tindakan yang dapat dikategorikan masuk dalam perkara pidana yang terjadi di dalam desa adat yang memiliki peraturan adat sendiri, maka akan diterapkan hukum adat sebagai solusi dalam menyelesaikan permasalahan hukum tersebut, jika sanksi dari perbuatan atau tindakan tersebut diselesaikan secara adat maka akan tercapai rasa keadilan baik oleh Pelaku maupun oleh korban, karena adanya ikatan yang kuat antara hukum adat yang diberlakukan dengan perasaan emosional yang saling terikat antara hukum adat dengan masyarakat yang ada dalam hukum tersebut. Penyelesaian secara adat bisa memberikan rasa adil tidak hanya pada korban, pelaku tetapi juga bisa memberikan rasa adil dan aman bagi masyarakat yang ada didalam jangkauan hukum adat dalam masyarakat tersebut, maka harus ada penguatan serta optimilisasi pemanfaatan hukum adat.
\end{abstract}

Kata Kunci: Pemanfaatan serta optimalisasi, hukum pidana adat, keadilan

Paris Langkis

Vol.1 Nomor 2, Maret 2021 


\section{Abstract:}

The existence of customary law is still felt to be very necessary to be maintained and defended in the midst of criminal, civil, state administration and other state laws. According to Soepomo's opinion, there are at least 4 (four) reasons to maintain the existence or existence of customary law, including because customary law (a) has a strong collective or communal nature; (b) has a religio-magical style in terms of life; (c) be overwhelmed by thoughts of all-concrete structuring, which means being very concerned about the multitude and repetition of the concrete relationships of life; and (d) has a visual character, which in a legal context is considered to occur only because it is determined by a visible sign. The writing of this article uses the normative juridical analysis method, which is an approach that uses the main legal material in the form of laws and regulations relating to the title and uses the analysis of applicable legal theories, concepts and principles regarding the extent to which the optimization of the application of criminal law is optimal. adat in solving problems and providing justice for both victims and perpetrators. If an act or action can be categorized as a criminal case that occurs in a customary village that has its own customary regulations, customary law will be applied as a solution in resolving these legal problems, if the sanctions for these actions or actions are resolved according to custom, it will be a sense of justice is achieved both by the perpetrator and by the victim, because of the strong bond between the customary law that is enforced and the emotional feeling that is mutually bound between customary law and the community that exists in the law. Customary resolution can provide a sense of justice not only to the victim, the perpetrator, but also to provide a sense of justice and security to communities that are within the reach of customary law in the community, so there must be strengthening and optimizing the use of customary law.

Keywords: Utilization and optimization, customary criminal law, justice

\section{A. PEDAHULUAN}

Terdapat salah satu pandangan dari Satjipto Rahardjo didunia hukum khususunya korelasi dari hukum adat dalam hukum nasional, yang mengatakan bahwa hukum tidak dapat dilepaskan dari konteks sosial budayanya, dimana hukum haruslah berjalan sesuai dengan kebaisaan yang berlaku dan hidu dalam masyarakat, pada Pandangan ini memperkuat pandangan Von Savigny yang sudah ada sebelumnya dimana beliau mengatakan bahwa hubungan hukum dan masyarakat ibarat jiwa dan raga, hukum adalah jiwa masyarakat itu.

Maka untuk memahami hukum adat yang merupakan salah satu cara untuk menyelesaikan permasalahan yan ada dalam masyarakat dalam kawasan atau lingkungan yang bisa dijangkau oleh hukum adat tertentu. Hukum adat merupakan hukum asli dalam suatu masyarakat tertentu, yang biasanya tidak tertulis, dimana pada masa dahulu dipergunakan sebagai pedoman bagi seluruh aspek kehidupan dalam masyarakat yang bersangkutan. Hal tersebut bukao berarti bahwa hukum adatselamanya adalah hukum yang tidak tertulis. Ada hukum adat tertulis, yaitu misalnya ciwacasana (kurang lebih tahuo 1000 pada zaman pemeriotahan Raja Dhannawangsa di Iawa Timur), dan awig-awig di Bali. Akan 
tetapi apabila dibandingkan dengan hukum adat yang tidak tertulis, maka hukum adat yang tidak tertulis jumlahnya sangat sedikit, sehingga tidak berpengaruh dan sering diabaikan.

\section{B. KAJIAN TEORI}

Tradisi penyelesaian sengketa masyarakat hukum adat didasarkan pada nilai filosofi kebersamaan (komunal), pengorbanan, nilai spiritual, dan keadilan. Dalam masyarakat hukum adat kepentingan bersama merupakan filosofi hidup yang sudah menancap didada setiap anggota masyarakat adat. Kepentingan bersama dijunjung tinggi yang melebihi kepentingan individu, sehingga dalam masyarakat adat dikenal adanya kepentingan bersama. Bila kepentingan bersama terwujud, maka dengan sendirinya kepentingan individual tidak terinjak-injak.

Sengketa yang terjadi antar individu maupun antar kelompok, dalam pandangan masyarakat hukum adat adalah tindakan yang mengganggu kepentingan bersama (komunal), dan oleh karena itu harus cepat diselesaikan secara arif dengan menggunakan pola penyelesaian adat, penyelesaian harus dilakukan oleh mekenisme hukum dan oleh orang yang dianggap mampu menyelesaikan permasalahan yang muncul.

Hukum adat adalah keseluruhan aturan tingkah laku positif yang di satu pihak mempunyai sanksi dan pihak lain dalam keadaan tidak dikodifikasikan dengan kata lain hukum adat adalah adat kebiasaan yang mempunyai akibat hukum. Sistem hukum adat bersumber kepada peraturan-peraturan yang tidak tertulis yang tumbuh dan berkembang dan dipertahankan dengan kesadaran hukum masyarakatnya, dan hukum adat itu mempunyai tipe tradisional dengan berpangkal pada kehendak nenek moyang, artinya untuk ketertiban hukumnya selalu diberikan penghormatan yang sangat besar bagi kehendak suci nenek moyang itu (Titik Triwulan Tutik, 2006).

Keberadaan Kepentingan dan kegunaan Hukum Adat itu, mengapa masih perlu dipelihara dan dihidupkan serta diberlakukan dalam kehidupan masyarakat, antara lain dapat kita ketahui dari uraian penjelas berikut ini. Dari catatan Van Kan, di dalam Uit de Geschiedenis onder Codificatie, kita mengetahui bahwa kepentingan atau kehendak bangsa Indonesia, pada di tahun 1948 setelah Indonesia menyatakan diri merdeka dari pemerintah kolonial Belanda, di masa itu sudah dirasakan sangat perlu adanya penetapan hukum-hukum yang berdasarkan pola di Belanda untuk diberlakukan di Nusantara. Ada banyak alasan mengapa pola Belanda yang dibuat sebagai dasarnya, antara lain karena sistem hukum Indonesia sendiri masih belum terbentuk dan nyata berlaku

Hubungan antara hukum dan kehidupan masyarakat memang berkaitan erat, hukum berperan besar dalam mewujudkan kehidupan yang tertib dan aman. Apabila terjadi hal-hal yang menyimpang maka peran hukum adat dapat dilihat secara lebih konkrit. Didalam lapangan hukum pidana, ada dua hukum berbeda yang digunakan oleh masyarakat yaitu hukum pidana yang bersumber kepada peraturan tidak tertulis dan hukum pidana yang bersumber pada KUHP serta peraturan yang tertulis ataupun kebiasaan yaitu hukum pidana adat.

Faktor diatas menyebabkan akhirnya mengunakan pilihan mengunakan dan memasukkan dalam kebijakan sistem hukum pemerintahan di masa sebelum terbentuknya hukum nasional Indonesia. Posisi-antara, yang terdapat di sela-selaitulah, Hukum Adat

Paris Langkis

Vol.1 Nomor 2, Maret 2021 
akan diberi tempat diantara hukum perdata, dagang, acara perdata, dan acara pidana, sebagaimana yang sebelumnya telah terjadi di dalam kebijakan pemerintahan kolonial bagi kepentingan ekonomi dan keamanan wilayah jajahan di kepulauan nusantara.

Perlu dan pentingnya hukum adat diterapkan dalam sebuah masyarakat tertentu ternyata sudah sejak lama ditemukan oleh para sarjana Belanda sebelumnya bahwa dari segi lingkup berlakunya hukum adat tidak ada kecocokan dengan hukum Barat terutama dalam perhubungan-perhubungan hukum bangsa di nusantara, mengenai hukum tanah penduduk desa untuk kepentingan agraria, dan sama sekali tidak mampu memenuhi tuntutan zaman bagi perekonomian dan perdagangan di masa itu. Untuk hal itulah, Van Vollenhoven melakukan riset yang hingga kini telah menjadi referensi babon mengenai perjuangan berlakunya hukum adat (Strijd van het Adatrecht) yang semula hanya bertujuan sebagai kritik keras terhadap pendapat pemerintahnya yang memberlakukan hukum barat di saat itu.

\section{METODE PENELITIAN}

Penulisan aetikel ini mengunakan metode analisis yuridis normative, yaitu pedekatan yang menggunakan bahan hukum utama berupa peraturan perundang-ndangan yang berhubungan dengan judul serta menggunakan penelaan teori-teori, konsep-konsep serta asas-ass hukum yang berlaku tentang sejauh mana optimalisasi penerapan hukum pidana secara adat dalam menyelesaikan permasalahan serta memberikan keadilan baik bagi korban dan pelaku.

\section{HASIL DAN PEMBAHASAN}

\section{Konsep Lembaga Adat di Nusantara}

Konsep Lembaga Adat terbentuk menjadi sistem hukum adat yang pada umumnya terdapat dan hidup berkembang di seluruh nusantara (kemudian menjadi wilayah hukum negara kesatuan Republik Indonesia). Bentuk badan sebagai subyek hukum dari persekutuan masyarakat adat itu, sekurang-kurangnya terdiri dari 4 (empat) unsur yakni:

a. tata susunan masyarakat yang bersifat tetap, seperti penghuni rumah besar atau jurai di Minangkabau, atau penamaan lain-lain yang semacamnya di daerah masyarakat adat lainnya.

b. Ada pengurus sendiri dengan struktur kepemimpinan yang terdiri dari ketua dan fungsi kepengurusan lainnya untuk memimpin masyarakat itu.

c. Ada harta pusaka sendiri yang diurus oleh pengurus bagi kemaslahatan semua masyarakat adat itu secara kolektif dan juga untuk keperluan yang bersifat privat kekeluargaan Harta kekayaan ini ada yang bersifat materil dan juga ada yang bersifat immateril.

d. Ada hukum yang berlaku sama bagi semua anggota masyarakat itu sendiri dan aturan itulah yang berlaku, diikuti serta ditaati.

Menurut pandanan dari Soepomo, bahwa kedudukan penduduk Indonesia yang serba berada mengakibatkan kesukaran-kesukaran dalam perkembangan ke arah satu hukum seragam. Lagi pula, keseragaman itu tidak perlu harus didasarkan pada sistem hukum Barat dangen kata lain hukum Belanda. Selain itu menurut Soepomo, terdapat nilai-nilai universal hukum adat tradisional yang meliputi adanya:

a. asas gotong royong;

Paris Langkis

Vol.1 Nomor 2, Maret 2021 
b. fungsi sosial manusia dan milik dalam masyarakat;

c. asas persetujuan sebagai dasar kekuasaan umum;

d. asas perwakilan dan permusyawaratan dalam sistem pemerintahan.

Pendapat dari Soepomo itu masih juga sejalan dengan pendapat dari Ter Haar, murid van Vollenhoven, yang sejak lama sudah berusaha supaya hukum adat dapat dipertahankan dan dilaksanakan sebagai hal yang sesuai dengan kebutuhan masyarakat bangsa Indonesia. Khususnya diterapkan kepada penduduk tani dalam masyarakatmasyarakat agraria, dan dari sistem hukum adat ini akan dapat dilakukan reorganisasi pengadilan, yang melaksanakan pengadilan desa dan memperbaiki peradilan mahkamah yang harus melakukan hukum adat.

Ciri-ciri dari masyarakat adat yang mendukung berlakunya hukum adat itu, digambarkan terjadi dalam hak-hak pertanahan dengan pengelompokan-pengelompokan diantaranya adalah:

a. orang yang membuka tanah;

b. orang yang memiliki pekarangan atau rumah atau tegalan;

c. orang yang tidak memiliki pekarangan atau tempat tinggal sebagai penumpang;

d. dan juga cara orang luar masuk ke dalam persekutuan hukum adat yang bisa dimulai dari masuk sebagai hamba atau budak;

a) karena pertalian perkawinan;

b) dengan jalan mengambil anak;

c) dalam hal masalah warisan;

d) perkawinan;

e) hubungan anak di dalam keluarga.

Mengenai tidak dikenalnya pembagian hukum dalam sistem hukum adat, Abbas mengatakan: Dalam sistem hukum adat, tidak dikenal pembagian hukum kepada hukum publik dan hukum privat. Akibatnya, masyarakat hukum adat tidak mengenal kategorisasi hukum pidana dan hukum perdata, sebagaimana dalam sistem hukum Eropa Kontinental. Istilah "sengketa" bagi masyarakat hukum adat bukan hanya ditujukan untuk kasus perdata, yang menitikberatkan pada kepentingan perorangan, tetapi sengketa juga digunakan untuk tindak pidana kejahatan atau pelanggaran. Makna sengketa bagi masyarakat hukum adat, ditujukan pada ketidakseimbangan sosial. Artinya, Jika terjadi sengketa dalam hukum perdata, atau kejahatan dan pelanggaran dalam hukum pidana, maka masyarakat hukum adat merasakan adanya ketidakseimbangan yang terjadi dalam kehidupan masyarakat hukum adat."

\section{Lembaga adat dalam realitas Modern Saat ini}

UUD NRI Tahun 1945, dalam Pasal 18B Ayat (2) menentukan "Negara mengakui dan menghormati kesatuan-kesatuan masyarakat hukum adat beserta hak-hak tradisionalnya sepanjang masih hidup dan sesuai dengan perkembangan masyarakat dan prinsip Negara Kesatuan RI, yang diatur dalam undang-undang." Ketentuan konstitusi itu pun sejalan dengan aturan dalam Pasal 3 UU No. 5 Tahun 1960 tentang Pokok-pokok Agraria, yang kemudian hari ditegaskan lagi secara lebih operasional ke dalam Peraturan Menteri Negara Agraria/Kepala Badan Pertanahan Nasional No. 5 Tahun 1999 tentang Pedoman Penyelesaian Masalah Hak Ulayat Masyarakat Hukum Adat.

Paris Langkis

Vol.1 Nomor 2, Maret 2021 
Substansi pemahaman secara entitas lembaga adat tampak dalam legitimasi pengakuan konstitusional oleh negara yang sangat tegas menyatakan penghormatan terhadap masyarakat hukum adat. Juga Undang-undang yang terkini berlaku tentang Penanganan Konflik Sosial (UU No. 7 Tahun 2012) telah mengatur adanya penyelesaian melalui lembaga adat. Namun, daya ikatnya tetap bersifat tidak final, karena bilamana dengan cara ini tidak selesai juga, maka harus diteruskan lagi menurut hukum acara yang berlaku (Eman Suparman, 2004).

Perkembangannya, pengakuan terhadap peradilan adat di Indonesia telah mengalami pasang surut. Pada masa orde baru, pemerintah membuat beberapa ketentuan yang membatasi bahkan menghilangkan lembaga peradilan adat. Pada Era reformasi, kedudukan lembaga peradilan adat kembali diberi ruang dan tempat seiring dengan menguatnya pengakuan terhadap masyarakat hukum adat. Masyarakat Hukum adat di Indonesia keberadaannya mendapat pengakuan dan perlindungan hukum yang jelas dan tegas di dalam Undang-Undang Dasar 1945 pasal 18 B ayat (2) mengatur bahwa negara mengakui dan menghormati kesatuan-kesatuan masyarakat hukum adat beserta hak-hak traditionalnya sepanjang masih hidup dan sesuai dengan perkembangan masyarakat dan prinsip Negara kesatuan Republik Indonesia yang diatur dalam undang-undang.

Lembaga adat merupakan kata yang berasal dari gabungan antara kata lembaga dan kata adat. Kata lembaga dalam bahasa Inggris disebut dengan institution yang berarti pendirian, lembaga, adat dan kebiasaan. Dari pengertian literatur tersebut, lembaga dapat diartikan sebagai sebuah istilah yang menunjukkan kepada pola perilaku manusia yang mapan terdiri dari interaksi sosial yang memiliki struktur dalam suatu kerangka nilai yang relevan. Sehingga lembaga adat adalah pola perilaku masyarakat adat yang mapan yang terdiri dari interaksi sosial yang memiliki struktur dalam suatu kerangka nilai adat yang relevan. Menurut ilmu budaya, lembaga adat diartikan sebagai suatu bentuk organisasi adat yang tersusun relative tetap atas pola-pola kelakuan, peranan- peranan, dan relasi-relasi yang terarah dan mengikat individu, mempunyai otoritas formal dan sanksi hukum adat guna tercapainya kebutuhan-kebutuhan dasar.

Pengertian lembaga adat menurut Peraturan Menteri Dalam Negeri Nomor 5 Tahun 2007 tentang Pedoman Penataan Lembaga Kemasyarakatan, Lembaga Adat adalah Lembaga Kemasyarakatan baik yang sengaja dibentuk maupun yang secara wajar telah tumbuh dan berkembang di dalam sejarah masyarakat atau dalam suatu masyarakat hukum adat tertentu dengan wilayah hukum dan hak atas harta kekayaan di dalam hukum adat tersebut, serta berhak dan berwenang untuk mengatur, mengurus dan menyelesaikan berbagai permasalahan kehidupan yang berkaitan dengan dan mengacu pada adat istiadat dan hukum adat yang berlaku.

Lembaga Adat berfungsi bersama pemerintah merencanakan, mengarahkan, mensinergikan program pembangunan agar sesuai dengan tata nilai adat istiadat dan kebiasaan-kebiasaan yang berkembang dalam masyarakat demi terwujudnya keselarasan, keserasian, keseimbangan, keadilan dan kesejahteraan masyarakat. Selain itu, Lembaga adat berfungsi sebagai alat kontrol keamanan, ketenteraman, kerukunan, dan ketertiban masyarakat, baik preventif maupun represif, antara lain:

a. Menyelesaikan masalah sosial kemasyarakatan,

Paris Langkis

Vol.1 Nomor 2, Maret 2021 
b. Penengah (Hakim Perdamaian) mendamaikan sengketa yang timbul di masyarakat.

Kemudian, lembaga adat juga memiliki fungsi lain selain fungsi-fungsi diatas, diantaranya yaitu:

a. Membantu pemerintah dalam kelancaran dan pelaksanaan pembangunan di segala bidang terutama dalam bidang keagamaan, kebudayaan dan kemasyarakatan.

b. Melaksanakan hukum adat dan istiadat dalam desa adatnya

c. Memberikan kedudukan hukum menurut adat terhadap hal-hal yang berhubungan dengan kepentingan hubungan sosial kepadatan dan keagamaan.

d. Membina dan mengembangkan nilai-nilai adat dalam rangka memperkaya, melestarikan dan mengembangkan kebudayaan nasional pada umumnya dan kebudayaan adat khususnya.

e. Menjaga, memelihara dan memanfaatkan kekayaan desa adat untuk kesejahteraan masyarakat desa adat.

\section{Hukum Pidana Adat di Indonesia}

Pada asasnya, terminologi hukum adat (Seminar Hukum Adat dan Pembangunan Hukum Nasional, 1976) berasal dari kata adatrecht dipergunakan oleh Snouck Hurgronye dan dipakai sebagai terminologi teknis yuridis oleh van Vollenhoven. Kemudian, terminologi hukum adat dikenal dalam zaman Hindia Belanda diatur ketentuan Pasal 11 Algemene Bepalingen van Wetgeving voor Indonesia (AB) dengan terminologi godsdientige wetten, volksinstelingen en gebruiken, ketentuan Pasal 75 ayat 3 Reglement op het Beleid der Regeling van Nederlands Indie (RR) dengan terminologi Instellingen en gebruiken des volks, berikutnya menurut ketentuan Pasal 128 Wet op de Staatsinrichting van Nederlandsch Indie atau Indische Saatsregeling (IS) dipergunakan terminologi godsdientige wetten en oude herkomsten dan berdasarkan ketentuan Stb. 1929 Nomor 221 jo Nomor 487 terakhir dipergunakan terminologi adatrecht.

Dikaji dari perspektif peraturan perundang-undangan Indonesia saat ini (ius constitutum) terminologi hukum adat dikaji dari perspektif asas, norma, teoretis dan praktik dikenal dengan istilah, "hukum yang hidup dalam masyarakat", "living law", "nilai-nilai hukum dan rasa keadilan yang hidup dalam masyarakat", "hukum tidak tertulis", "hukum kebiasaan", dan lain sebagainya. Selain itu, dari dimensi demikian terminologi hukum adat beserta masyarakat adatnya mempunyai korelasi erat, integral dan bahkan tak terpisahkan yang lazim diungkapkan dalam bentuk petatah petatih. Sebagai contoh, misalnya dalam masyarakat Aceh dikenal dengan ungkapan "matee anek mepat jerat matee adat phat tamita" yang diartikan kalau anak mati masih dapat dilihat pusaranya, akan tetapi kalau adat dihilangkan/mati, maka akan sulit dicari. Ungkapan lainnya, berupa "murip $i$ kanung edet, mate i kanung bumi" yang berarti bahwa keharusan mengikuti aturan adat sama dengan keharusan ketika mati harus masuk ke perut bumi.

Terminologi hukum pidana adat, delik adat, hukum pelanggaran adat atau hukum adat pidana cikal bakal sebenarnya berasal dari hukum adat. Sistem sosial adalah suatu sistem interaksi, jadi suatu tindakan manusia, yang melibatkan sejumlah individu. Sistem tindakan manusia itu, sebagai suatu sistem, tersusun atas jumlah bagian, yang disebut

Paris Langkis

Vol.1 Nomor 2, Maret 2021 
subsistem, yang saling berkaitan dan saling mendukung. Tiap bagian atau subsistem mempunyai fungsi tertentu terhadp sistem yang meliputinya. Talcott Parsons menyebut ada 4 (empat) fungsi yang meliputi, yaitu (Doyle P. Johson, 1985):

a. Fungsi adaptasi (Adaptation), yaitu penyesuaian diri terhadap situasi dan lingkungan. Fungsi ini menunjuk pada keharusan bagi sistem-sistem social untuk menghadapi lingkungannya;

b. Fungsi pencapaian tujuan (Goal attainment), yang merupakan pencapaian sasaran atau tujuan. Parsons beranggapan bahwa suatu tindakan diarahkan padatujuannya. Namun perhatian yang diutamakan di sini bukanlah tujuan pribadi individu, melainkan tujuan bersama para anggota dalam suatu sistem sosial;

c. Fungsi integrasi (Integration) adalah memadukan atau mengakomodasikan pelbagai faktor yang terkait pada pencapaian tujuan. Yang terdiri atas penjaminan koordinasi yang perlu antara unit-unit dari sistem sosial berkaitan dengan kontribusi tiap unit pada organisasi dan berfungsinya secara keseluruhan;

d. Fungsi pemeliharaan pola atau latensi (patterns maintence atau latency) yaitu melestarikan pola-pola yang sudah terbentuk berdasarkan nilai-nilai.

Hukum adat sebagai suatu model sosial dari Talcott Parsons titik beratnya pada fungsi integrasi. H.R. Otje Salman lebih lanjut menyebutkan hukum diarahkan untuk mengakomodasikan keseluruhan sistem sosial kemasyarakatan. Fungsi ini meliputi sistem kaidah (sistem norma) yang bertugas untuk mengoreksi perilaku yang menyimpang dari kaidah-kaidah yang bersangkutan. Jadi kaidahkaidah itu dalam integrasi sosial menuntut perilaku tertentu yang mewujudkan peranan-peranan tertentu. Dengan demikian, kaidahkaidah ini merupakan kerangka orientasi perilaku manusia (anggota sistem kemasyarakatan). (H.R. Otje Salman, 2007)

Hukum adat tidak saja merupakan adat-adat yang mempunyai akibat-akibat hukum, atau keputusan-keputusan yang berwibawa dari kepala-kepala rakyat, karena antara adat yang mempunyai akibat hukum dan yang tidak mempunyai akibat hukum tidak ada pemisahan yang tegas. Dengan kata lainbahwa setiap kebiasaan yang kemudian menjadi perilaku sehari-hari merupakan hukum adat (Soerjono Soekanto, 1982). Polarisasi hukum adat tersebut tidak membedakan antara hukum pidana adat, hukum perdata adat, hukum tata negara adat dan lain sebagainya. Konsekuensi logisnya bahwa hukum adat tidak mengenal pemisahan secara tegas antara hukum pidana dengan hukum perdata (privat) dan diantara keduanya saling berkorelasi satu sama lain. Sehubungan dengan hal tersebut, tidak ada perbedaan prinsip dalam prosedur penyelesaian perkara-perkara pelanggaran hukum adat. Jika terjadi pelanggaran para fungsionaris hukum (penguasa/kepala adat) berwenang mengambil tindakan konkret, baik atas inisiatif sendiri atau berdasarkan pengaduan pihak yang dirugikan.

Eksistensi norma, asas dan praktek hukum pidana adat sampai sekarang masih diterapkan hakim yang bertitik tolak pada hukum pidana adat atau mengganggap hukum pidana adat masih berlaku seperti dalam praktek yurisprudensi Mahkamah Agung RI salah satunya tercermin pada Putusan Mahkamah Agung Nomor 1644 K/Pid/1988 tanggal 15

Paris Langkis

Vol.1 Nomor 2, Maret 2021 
Mei 1991 (H.R. Otje Salman Soemadiningrat, 2002). yang menyatakan bahwa terhadap terdakwa yang telah melakukan perbuatan hubungan kelamin di luar perkawinan dijatuhi sanksi adat (reaksi adat) oleh kepala adat, tidak dapat diajukan lagi (untuk kedua kalinya) kepada badan peradilan Negara (pengadilan negeri) dengan dakwaan yang sama melanggar hukum adat dan dijatuhkan hukuman penjara menurut ketentuan hukum pidana.

Dikaji dari perspektif asas, teori, norma, praktek dan prosedurnya maka

Hukum pidana adat penjatuhan sanksi adat (obat adat) hakikatnya bersifat untuk pemulihan keseimbangan alam magis, pemulihan alam kosmos guna mengembalikan pada keseimbangan yang terganggu agar bersifat religio magis kembali. Penjatuhan sanksi pidana ini penting eksistensinya. Di satu sisi, penjatuhan sanksi pidana bersifat preventif dan represif dan di sisi lainnya pemulihan kesimbangan magis yang terganggu sehingga diharapkan masyarakat hukum adat tersebut seperti sedia kala.

Pada hakikatnya, "sanksi pidana" merupakan "penjamin / garansi yang utama / terbaik" atau (prime guarantor) dan sekaligus sebagai "pengancam yang utama" (prime threatener) atau serta merupakan alat atau sarana terbaik dalam menghadapi kejahatan. Konklusi dasar asumsi Herbert L. Packer ini diformulasikan dengan redaksional sebagai berikut (Herbert L. Packer, 1968):

a. Sanksi pidana sangatlah diperlukan; kita tidak dapat hidup sekarang maupun di masa yang akan datang tanpa pidana. (The criminal sanction is indispensable; we could not, now or in the foresecable future, get along without it)

b. Sanksi pidana merupakan alat atau sarana terbaik yang tersedia, yang kita miliki untuk menghadapi kejahatan-kejahatan atau bahaya besar dan segera serta untuk menghadapi ancaman-ancaman dari bahaya. (The criminal sanction is the best available device are have for dealing with gross and immediate harm and threats of harm)

c. Sanksi pidana suatu ketika merupakan "penjamin yang utama/terbaik" dan suatu ketika merupakan "pengancam yang utama" dari kebebasan manusia. Ia merupakan penjamin apabila digunakan secara cermat dan manusiawi; ia merupakan pengancam apabila digunakan secara sembarangan dan secara paksa. (The criminal sanction is at once prime guarantor; used indiscriminately and coercively, it is threatener).

Konsekuensi logis diakui dan adanya dasar hukum yang tegas eksistensi hukum yang hidup (hukum pidana adat) akan memberikan tugas, tanggung jawab dan beban relatif lebih berat kepada hakim untuk lebih dapat memahami dan menggali nilai-nilai hukum yang hidup dalam masyarakat. Hakim harus benarbenar memahami perasaan masyarakat, keadaan masyarakat, terlebih masyarakat Indonesia yang majemuk dengan pelbagai macam adat istiadat, tradisi dan budayayang berbeda-beda yang tetap dipertahankan sebagai hukum yang hidup. Soedarto (Soedarto, 1983) menyebutkan bahwa mata, pikiran dan perasaan hakim harus tajam untuk dapat menangkap apa yang sedang terjadi dalam masyarakat, agar supaya keputusannya tidak kedengaran sumbang. Hakim dengan seluruh kepribadiannya harus bertanggung jawab atas kebenaran putusannya baik secara formal maupun materiil.

\section{Konsep dan Teori Keadilan}

Terkait dengan itu, ilmu hukum menawarkan sebuah konsep yang diyakini mampu menjawab permasalahan kesenjangan rasa keadilan hukum dalam masyarakat adat. Konsep 
tersebut adalah "restorative justice" (keadilan restoratif) yang dapat diartikan sebagai sebuah konsep pemikiran yang merespons pengembangan sistem peradilan pidana dengan menitik beratkan pada kebutuhan pelibatan masyarakat dan korban yang dirasa tersisihkan dengan mekanisme yang bekerja pada sistem peradilan pidana yang ada saat ini (Eva Achjani Zulfa, 2011). Dalam pengertian itu, keadilan restoratif dapat ditempatkan dalam posisi sebagai salah usaha untuk mencari penyelesaian konflik secara damai di luar pengadilan.

Penyelesaian perkara pidana adat melalui lembaga adat justru mendapat tempat terhormat dalam kerangka keadilan restoratif. Namun masalahnya, sekalipun di Indonesia banyak hukum adat yang bisa menjadi "restorative justice", namun seperti dijelaskan di muka, keberadaannya tidak mendapat tempat yang memadai dalam hukum perundangundangan. Padahal hukum adat diyakini mampu menyelesaikan konflik yang muncul di masyarakat dan memberikan kepuasan bagi para pihak yang berkonflik.

Hukum pidana adat dijiwai oleh sifat kekeluargaan yang religius magis, dimana yang diutamakan bukanlah rasa keadilan perseorangan melainkan rasa keadilan kekeluargaan, sehingga penyelesaian kasus yang dilakukan secara damai diyakini dapat membawa kerukunan (harmoni). Hukum pidana adat tidak bermaksud menunjukkan hukum dan hukuman apa yang harus dijatuhkan bila terjadi pelanggaran, tapi yang menjadi tujuannya adalah memulihkan kembali hukum yang pincang sebagai akibat terjadinya pelanggaran.

Diskresi berkenaan dengan pengambilan keputusan yang tidak terikat pada hukum, dimana penilaian pribadi juga memegang peranan. Ada beberapa faktor yang menyebabkan kewenangan diskresi menjadi sesuatu yang sangat penting dalam penegakan hukum, yaitu (Soerjono Soekanto, 2007):

a. tidak ada peraturan perundang-undangan yang sedemikian lengkapnya, yang dapat mengatur semua perilaku manusia,

b. adanya kelambatan-kelambatan untuk menyesuaikan perundang-undangan dengan perkembangan masyarakat, sehingga menimbulkan ketidakpastian,

c. kurangnya biaya untuk menerapkan perundang-undangan sebagaimana yang dikehendaki pembentuk undang-undang,

d. adanya kasus-kasus individual yang memerlukan penanganan secara khusus.

Dalam konsep Plato tentang keadilan dikenal adanya keadilan individual dan keadilan dalam negara. Untuk menemukan pengertian yang benar mengenai keadilan individual, terlebih dahulu harus ditemukan sifat-sifat dasar dari keadilan itu dalam negara, untuk itu Plato mengatakan (The Liang Gie, 2002): "let us enquire first what it is the cities, then we will examine it in the single man, looking for the likeness of the larger in the shape of the smaller". Walaupun Plato mengatakan demikian, bukan berarti bahwa keadilan individual identik dengan keadilan dalam negara. Hanya saja Plato melihat bahwa keadilan timbul karena penyesuaian yang memberi tempat yang selaras kepada bagian-bagian yang membentuk suatu masyarakat. Keadilan terwujud dalam suatu masyarakat bilamana setiap anggota melakukan secara baik menurut kemampuannya fungsi yang sesuai atau yang selaras baginya.

Jadi fungsi dari penguasa ialah membagi bagikan fungsi-fungsi dalam negara kepada masing-masing orang sesuai dengan asas keserasian. Pembagian kerja sesuai dengan bakat,

Paris Langkis

Vol.1 Nomor 2, Maret 2021 
bidang keahlian dan keterampilan setiap orang itulah yang disebut dengan keadilan. Konsepsi keadilan Plato yang demikian ini dirumuskan dalam ungkapan "giving each man his due" yaitu memberikan kepada setiap orang apa yang menjadi haknya. Untuk itu hukum perlu ditegakkan dan Undang-undang perlu dibuat.

Pembahasan yang lebih rinci mengenai konsep keadilan dikemukakan oleh Aristoteles. Jika Plato menekankan teorinya pada keharmonisan atau keselarasan, Aristoteles menekankan teorinya pada perimbangan atau proporsi. Menurutnya di dalam negara segala sesuatunya harus diarahkan pada cita-cita yang mulia yaitu kebaikan dan kebaikan itu harus terlihat lewat keadilan dan kebenaran. Penekanan perimbangan atau proporsi pada teori keadilan Aristoteles, dapat dilihat dari apa yang dilakukannya bahwa kesamaan hak itu haruslah sama diantara orang-orang yang sama (J.H. Rapar, 2019). Maksudnya pada satu sisi memang benar bila dikatakan bahwa keadilan berarti juga kesamaan hak, namun pada sisi lain harus dipahami pula bahwa keadilan juga berarti ketidaksamaan hak. Jadi teori keadilan Aristoteles berdasar pada prinsip persamaan. Dalam versi modern teori itu dirumuskan dengan ungkapan bahwa keadilan terlaksana bila halhal yang sama diperlukan secara sama dan hal-hal yang tidak sama diperlakukan secara tidak sama.

Secara teoritis konsep keadilan Plato berdasar pada aliran filsafat idealisme, sedangkan konsep keadilan Aristoteles bertolak dari aliran filsafat realisme. Filsafat Plato mendasarkan diri pada alam ide yang bersifat mutlak dan abadi. Landasan filsafatnya ialah percaya dan menerima sepenuhnya alam nyata sebagai obyektifitas. Dalam pandangan filsafat ini alam nyata diterima sepenuhnya sebagai suatu totalitas yang menjadi sumber dari segala apa yang ada (J.H. Rapar, 1993). Alam nyata tersusun dan bertalian secara hirarkis serta membentuk suatu totalitas yang di dalamnya makna dan ketertiban dapat dicapai manusia melalui akal pikirannya. Akal merupakan alat untuk mengetahui dan pengetahuan tersebut memberikan norma-norma mengenai baik buruk yang berguna untuk manusia, seperti dikatakan oleh Plato keadilan ialah susunan ketertiban dari orangorang yang menguasai diri sendiri (J.H. Rapar, 1993). Sebaliknya Aristoteles menekankan filsafatnya pada kesadaran, maksudnya dalam pandangan Aristoteles titik sentralnya adalah kesadaran yang ada pada subyek yang berpikir.

Konteks pemikiran modern tentangkeadilan dalam kamus Bahasa Indonesia istilah keadilan berasal darik kata adil, artinya tidak memihak, sepatutnya, tidak sewenangwenang. Jadi keadilan diartikan sebagai sikap atau perbuatan yang adil. Di dalam literatur Inggris istilah keadilan disebut dengan "justice" kata dasarnya "jus". Perkataan "jus" berarti hukum atau hak. Dengan demikian salah satu pengertian dari "justice" adalah hukum.

Makna keadilan sebagai hukum, kemudian berkembang arti dari kata "justice" sebagai "lawfullness" yaitu keabsahan menurut hukum. Pengertian lain yang melekat pada keadilan dalam makna yang lebih luas adalah "fairness" yang sepadan dengan kelayakan. Ciri adil dalam arti layak atau pantas, dapat dilihat dari istilah-istilah yang digunakan dalam ilmu hukum. Misalnya "priciple of fair play" yang merupakan salah satu asas-asas umum pemerintahan yang baik, "fair wage" diartikan sebagai upah yang layak yang sering ditemui dalam istilah hukum ketenagakerjaan. Hal yang sama dikemukakan dalam konsep keadilan Aristoteles yang disebutnya dengan "fairness in human action", Keadilan adalah kelayakan dalam tindakan manusia.

\section{Paris Langkis}

Vol.1 Nomor 2, Maret 2021 
Berbagai literatur hukum banyak teori-teori yang berbicara mengenai keadilan. Salah satu diantara teori keadilan itu adalah teori etis, menurut teori ini hukum sematamata bertujuan keadilan. Isi hukum ditentukan oleh keyakinan yang etis tentang yang adil dan tidak adil (Van Apeldoorn, 1995). Hukum menurut teori ini bertujuan untuk merealisir atau mewujudkan keadilan. Pemikiran filsafat tentang keadilan ini, terutama yang dipandang dari sudut filsafat hukum, sesuai dengan sudut pandang teori tentang tiga lapisan ilmu hukum yang meliputi dogmatik hukum, teori hukum dan filsafat hukum, sangat bermanfaat juga pada akhirnya bagi praktek hukum. Melalui pemikiran yang mendasar tentang apa yang menjadi hak yang telah menjadi buah pemikiran, dari beberapa ahli filsafat mulai dari Aristoteles sampai pada ahli filsafat masa kini, dapat disediakan referensi bagi pengambil keputusan untuk mengarahkan dan menjalankan fungsi pengaturan dalam praktek hokum.

Pemikiran keadilan dalam hubungannya dengan hukum sejak lama sudah dikemukakan oleh Aristoteles dan Thomas Aquinus dengan mengatakan sebagai berikut (Radbruch \& Dabin, 1950): Justice forms the substance of the law, but his heterogeneous substance is composed of three elements: an individual element: the suum cuiquire tribuere (individual justice): a social element: the changing fundation of prejudgments upon which civilization reposes at any given moment (social justice), and a political element, which is based upon the reason of the strongest, represented in the particular case by the state (justice of the state).

Hal ini menunjukkan ada pengaruh timbal balik antara hukum dan keadilan, yaitu bahwa hukum diciptakan berdasarkan nilai-nilai atau kaidah-kaidah moral yang adil, yang sudah ada terlebih dahulu dan yang telah hidup dalam masyarakat, jadi tugas pembentuk undang-undang hanya merumuskan apa yang sudah ada. Sedangkan dilain pihak terdapat kemungkinan bahwa perumusan hukum itu sendiri hanya bersifat memberikan interpretasi, atau memberikan norma baru termasuk norma keadilan. Tentang apa yang dimaksud dengan keadilan meliputi dua hal, yaitu yang menyangkut hakekat keadilan dan yang menyangkut dengan isi atau norma, untuk berbuat secara konkrit dalam keadaan tertentu.

Teori lain yang berbicara tentang keadilan adalah teori yang dikemukakan oleh John Rawls (John Rawls, 2006). Dalam teorinya dikemukakan bahwa ada tiga hal yang merupakan solusi bagi problema keadilan. Pertama prinsip kebebasan yang sama bagi setiap orang (principle of greatest equal liberty), tentang hal ini dirumuskan oleh John Rawls sebagai berikut: Each person is to have an equal right to the most extensive basic liberty compatible with a semilar liberty of thers. Rumusan ini mengacu pada rumusan Aristoteles tentang kesamaan, oleh karenanya juga kesamaan dalam memperoleh hak dan penggunaannya berdasarkan hukum alam. Rumusan ini inhern dengan pengertian equal yakni sama atau sederajat diantara sesama manusia. Usaha memperbandingkan ini juga secara tidak langsung merupakan pengakuan atau konfirmasi bahwa manusia selalu hidup bersama yang menurut Aristoteles disebut sebagai makhluk sosial, sehingga penentuan hak atau keadilan yang diterapkan adalah keadilan yang memperhatikan lingkungan sosial atau dengan kata lain harus merupakan keadilan sosial.

\section{E. KESIMPULAN}

\section{Paris Langkis}

Vol.1 Nomor 2, Maret 2021 
Hukum adat adalah salah satu cara yang cukup efektif Menurut pendapat dari Soepomo, ada sekurang-kurangnya 4 (empat) alasan untuk mempertahankan eksistensi atau keberadaan hukum adat diantaranya yakni karena hukum adat (a) mempunyai sifat kebersamaan atau komunal yang kuat; (b) mempunyai corak religio-magis dalam pandangan hidup; (c) diliputi oleh pikiran penataan serba konkrit, yang artinya sangat memperhatikan banyaknya dan berulangulangnya perhubungan hidup yang konkrit; dan (d) mempunyai sifat yang visual, yang dalam perhubungan hukum dianggap hanya terjadi oleh karena ditetapkan dengan suatu ikatan tanda yang dapat dilihat.

Permasalahan pidana yang terjadi pada desa adat yang masih memegang teguh adat serta peraturan hukum yang berlaku masih hidup dan berkembang dalam masyarakat, penyelesaian adat dianggap lebih adil bagi semua pihak,baik korban yang merasa dibalaskan atas kesalahan yang dilakukan oleh pelaku, serta pelaku yang merasa adil karena telah menebus ksalahannya dengan cara-caya yang disepakati bersama dan berlaku dikawasan hukumadat.

Penyelesaian secara adat saat ini memang masih diperlukan demi terwujudnya rasa keadilan yang merupakan tujuan dari hukum itu sendiri, banyaknya daerah serta pemahaman yang berbeda dari masing-masing masyarakat dan luasnya wilayah di Indonesia tentunya akan menimbulkan masalah dalam penegakan hukum secara nasional, serta kepercayaan dari masingmasing indivudu maupun kelompok masyarakat yang lebih mempercayai kepercayaan serta kearifan lokal yang secara turun temurun dianut dan dijalankan oleh masyarakat.

Keberadaan serta pemanfaatan dan optimalisasi penggunaan hukum pidana secara adat dalam menciptakan keadilan bagi korban dan pelaku sudah terbukti ampuh dan lebih bisa diterima oleh semua orang, sudah sepantasnya hukum adat dilestarikan sehingga sangksi-sangksi pidana secara adat bisa diterapkan serta menghasilkan rasa keadailan bagi semua, serta efek berkelanjutan dari perbuatan pidana bisa diminimalisirkan.

\section{REFERENSI}

Ansorie Sabuan. et.all. (1990). Hukum Acara Pidana, Bandung: Angkasa.

Apong Herlina. et.all. (2004.). Perlindungan Terhadap Anak yang Berhadapan dengan Hukum, Buku Manual Pelatihan untuk Polisi, Jakarta: Polri dan Unicef.

Departemen Hukum dan HAM RI. (2004). Konsep Rancangan UU tentang KUHP, Direktorat Jenderal Peraturan Perundang-undangan Departemen Hukum dan HAM RI.

Datoek Toeah, (tanpa tahun) Tambo Alam Minangkabau, Bukit Tinggi: Penerbit Pustaka Indonesia.

Eva Achjani Zulfa. (2011). Pergeseran Paradigma Pemidanaan, Bandung: Lubuk Agung.

Hamid Shahab. (1999). Menyingkap dan Meneropong UU No. 30 Tahun 1999, Djambatan. Harahap Yahya. (1996). Laporan Akhir Penelitian Hukum tentang Penyelesaian Sengketa di Luar Pengadilan, Depkeh RI. 
Hazairin, Rejang, dalam Surojo Wignjodipuro, I Made Widyana. (2009) Alternatif Penyelesaian Sengketa (ADR), Penerbit PT Fikahati Aneska bekerjasama dengan BANI, Jakarta: Gunung Agung.

Nasroen. (1983). Dasar Falsafah Adat Minangkabau; dalam Surojo Wignjodipuro, Jakarta: Gunung Agung

Otje Salman Soemadininggrat. (2002). Rekonseptualisasi Hukum Adat Kontemporer, Bandung: Alumni.

Simanjuntak Nikolas. (2009). Acara Pidana Indonesia dalam Sirkus Hukum, Jakarta: Ghalia Indonesia.

Snouck Hurgronje. (1982). De Atjehers, Het Gajoland, dalam Surojo Wignjodipuro, Jakarta: Gunung Agung.

Soepomo, Bab-bab tentang Hukum Adat; dalam Surojo Wignjodipuro, Jakarta: Gunung Agung, 1983.

Soepomo. (1959) Kedudukan Hukum Adat Dikemudian Hari, Pustaka Rakyat Jakarta.

Soekanto, Meninjau Hukum Adat Indonesia; dalam Surojo Wignjodipuro, Jakarta: Gunung Agung, 1983.

Surojo Wignjodipuro. (1983). Pengantar dan Asas-asas Hukum Adat, Jakarta: Gunung Agung

Syahrul Ricky. (1996). Suatu Tinjauan tentang Relevansi Azas Legalitas dengan Tindak Pidana Adat Sumbang-Salah di Minangkabau (Studi Kasus di PN Batusangkar), Universitas Andalas Padang

Soerjono Soekanto. (2007). Faktor-faktor yang Mempengaruhi Penegakan Hukum, Jakarta: PT Raja Grafindo Persada.

Ter Haar B., Bzn. (1983). Beginselen en stelsel van Adatrecht; dalam Surojo Wignjodipuro, Jakarta: Gunung Agung.

Togar Nainggolan, OFMCap. (2006). Batak Toba di Jakarta Kontinuitas dan Perubahan Identitas, disertasi di Univ Nijmegen, Belanda, Percetakan Bina Media, 2006. 